\title{
DISTRIBUIÇÃO ESPACIAL DE ACIDENTES POR ANIMAIS PEÇONHENTOS NO ESTADO DE SÃO PAULO ENTRE OS ANOS DE 2007 E 2012.
}

\author{
SPATIAL DISTRIBUTION IN ACCIDENTS BY VENOMOUS ANIMALS IN SÃO \\ PAULO STATE BETWEEN THE YEARS 2007 AND 2012. \\ P. E. CARRARO ${ }^{1 *}$, F. O. BARBOSA ${ }^{1}$, J. H. BEGALI ${ }^{1}$, M. S. RUBIO ${ }^{1}$, K. P. BÜRGER ${ }^{1}$
}

\section{RESUMO}

Os acidentes por animais peçonhentos são de notificação obrigatória, pois suas informações permitem dar subsídios ao controle e prevenção, além da produção e distribuição dos diferentes tipos de soro existentes no país. As notificações são, então, realizadas pelo SINAN quando ocorrem acidentes com serpentes, escorpiões, aranhas, taturanas, lagartas e abelhas. O objetivo do estudo foi analisar e avaliar a distribuição espacial dos acidentes por animais peçonhentos no Estado de São Paulo entre os anos de 2007 e 2012. Os dados foram obtidos no SINAN, IBGE e CATI. Posteriormente, foram tabulados no Excel ${ }^{\circledR}$ e geoprocessados no MapInfo. Observa-se no mapa grid que os acidentes se concentraram em 15 municípios ao longo das regiões nordeste, leste e sudeste do Estado, tendo uma taxa de incidência de 2,1/1000 habitantes. A alta incidência de casos em municípios populosos como São Paulo, Campinas e Ribeirão Preto, pode ser explicada através do crescimento urbano associado ao desmatamento do habitat natural, acúmulo de lixo, necessidade de abrigo e a busca por alimentos, dos quais atraem principalmente escorpiões, aranhas e serpentes. Olímpia, Araraquara, Piracicaba e Patrocínio Paulista possuem alta produção de cana-de-açúcar, fato que contribui para serem os quatro municípios com maior número de casos, pois os estoques da produção dessas lavouras aproximam os roedores, atraindo as serpentes. Ademais, mesmo sendo proibida, a queimada desta estimula a fuga dos animais para locais seguros. Conclui-se, então, que os municípios populosos e também com alta produção de cana-de-açúcar podem ser fatores de risco envolvidos com a ocorrência de acidentes por animais peçonhentos.

PALAVRAS-CHAVE: EPIDEMIOLOGIA. GEOPROCESSAMENTO. SAÚDE. MUNICÍPIOS. ENVENENAMENTO.

AGRADECIMENTOS: CAPES

ÁREA TEMÁTICA: Epidemiologia 